\title{
PRAKTIK POLITIK TATA RUANG DI KABUPATEN TUBAN DALAM PROSES INDUSTRIALISASI
}

\author{
Bayu Priambodo ${ }^{1}$, Muhammad Chabibi ${ }^{2}$ \\ ${ }^{1}$ Fakultas Ilmu Sosial dan Ilmu Politik, UPN Veteran Jawa Timur \\ bayu.p.adneg@upnjatim.ac.id \\ ${ }^{2}$ IKHAC Mojokerto \\ chabibi.akib@gmail.com
}

\begin{abstract}
Spatial planning has only been seen as an effort to meet development growth and only focuses on economic development. However spatial planning should not only focus on the economic sector but should also pay attention to other crucial sectors. This indicates that it does not take into account the zoning and purpose of spatialisation. This study attempts to look at ow the spatial planning process in Tuban Regency is undergoing a process of industrialization because many large factories are relocating to the Tuban area. The relocation of the factory to the Tuban area has increased the practice of spatial planning politics. The practice of spatial planning politics in Tuban Regency in this study is analyzed using Lefebvre's point of view which states that there are three parties to spatial planning. The method in this study is qualitative and the data collection technique uses the interview method. The results of this research show that the practice of space can be seen from how the government, the private sector and the community collaborate with each other to provide space so that industrialization can run. Many large factories are starting to be built in the Tuban area. The representation of space can be seen from how the government of Tuban Regency plans the arrangement so that there is an even distribution in each region. The northern and western regions are more focused on industrialization. The southern region is more focused on agricultural areas. the central region is focused on the center of government and trade and for the east it is focused on tourist attractions. The third is the representation space where this can be seen from how the government of Tuban Regency makes efforts to control the conversion of agricultural land for food. This is done because every year the agricultural land in Tuban Regency is decreasing so it needs to be maintained to maintain food security.
\end{abstract}

Keywords: Tuban Regency spatial planning, spatial practice, spatial representation.

\section{PENDAHULUAN}

Tata ruang wilayah merupakan salah satu persoalan krusial dewasa ini. Secara fisik, perkembangan wilayah selalu diikuti oleh semakin bertambah luasnya kawasan yang terbangun. Pertambahan penduduk dan aktivitas ekonomi di satu sisi, dan di sisi lain, keterbatasan lahan adalah problematika regional yang menyebabkan efisiensi pemanfaatan ruang menjadi tuntutan dan keharusan yang tidak dapat dihindari. Permasalahan tersebut telah diatasi dengan pengambilan serangkaian kebijakan dalam pengembangan daerah sebagai wilayah permukiman, industri, jaringan jalan, jaringan air minum, bangunan umum, maupun jalur hijau yang merupakan sarana dan prasarana dalam pengembangan tata ruang (Simatupang, 2015).

Penataan ruang di Indonesia masih dilihat hanya sebatas untuk memenuhi pertumbuhan pembangunan dan cenderung berorientasi pada upaya untuk mencapai target pertumbuhan ekonomi, ataupun untuk memenuhi kebutuhan pengembangan suatu kawasan tertentu yang tak bisa dihindari. Orientasi penataan ruang yang demikian kurang mempertimbangkan tujuan penataan dan penggunaan ruang yang sesuai dengan peruntukannya dan urgensitasnya. Secara konseptual, semestinya rencana tata ruang dikonsepkan sebagai suatu rencana yang disusun menyeluruh dengan menganalisis segala aspek serta faktor pengembangan dan pembangunan dalam suatu rangkaian yang terpadu. Konsep tersebut 
berupa uraian-uraian kebijakan dan langkah-langkah yang bersifat mendasar dilengkapi dengan data serta petapenggunaan ruang.

Penataan ruang sendiri telah diatur dalam Undang-undang No. 26 tahun 2007 tentang Penataan Ruang dimana di dalamnya terdapat unsur penting yang harus diperhatikan terutama terkait dengan keamanan masyarakat, kenyamanan masyarakat dalam menjalankan kegiatan sosial dan penerapan nilai budaya dalam suasana damai, produktivitas yang terjamin dalam kegiatan perekonomian dan peningkatan kesejahteraan masyarakat, serta unsur berkelanjutan dimana dalam penataan ruang harus memperhatikan kualitas lingkungan yang dapat dijaga untuk memenuhi kebutuhan masyarakat saat ini dan generasi yang akan datang.

Pada suatu daerah, penataan ruang merupakan salah satu aspek mendasar yang memiliki pengaruh besar dalam proses perkembangan dan pembangunan sebuah daerah. Perkembangan penduduk dan pertumbuhan dunia usaha selalu berkaitan erat dengan ketersediaan lahan atau ruang, maka masalah penataan ruang menjadi sangat penting untuk dioptimalkan pemanfaatannya, secara baik, efisien dan berdaya guna bagi masyarakat dan dunia usaha. Rencana Tata Ruang di Kabupaten Tuban menarik untuk diamati lebih mendalam melihat adanya penataan ruang dan lahan yang cukup signifikan yang mengarah pada sektor Industri namun tetap mempertahankan dan memperhatikan ketahanan pangan.

Penataan ruang dimaksudkan pula untuk memberikan gambaran kepada para penggunanya tentang spesifikasi pemanfaatan ruang, sekaligus akan menjadi pedoman dalam merencanakan kegiatankegiatan yang relevan dan berdaya guna. Penataan ruang dalam konteks demikian sistem alokasi ruang dimaksudkan untuk mengalokasikan letak, luas, dan atribut lain seperti jenis dan intensitas kegiatan agar dapat dimanfaatkan semaksimal mungkin tanpa harus mengorbankan kelestarian dan merusak lingkungan sebagaimana telah diatur di dalam Peraturan Perda Kabupaten Tuban Nomor 09 Tahun 2012 tentang Rencana Tata Ruang Wilayah Kabupaten Tuban Tahun 2012-2032.

Pengambilan kebijakan mengenai tata ruang di Kabupaten Tuban dapat dianggap sebagai politik tata ruang di mana ia merupakan tahap proses kebijakan yang telah diadopsi oleh para elit pemerintahan dan para spekulan lahan atau ruang melalui mobilisasi aturan kebijakan dan sumber daya yang ada. Ruang tidak bisa lepas dari politik dan politik tidak bisa lepas dari kekuasaan sehingga politik tata ruang merupakan pengejewantahan dari kekuasaan penguasa untuk mendominasi ruang-ruang yang direncanakan dan diabstraksikan. Secara politis, ruang berguna dapat memfasilitasi pengendalian sistem kebijakan untuk memudahkan mobilitas sumber daya yang dimiliki oleh para perencana, pengembang atau arsitek perkotaan. Terlebih lagi, hubungan arsitektur dan perkotaan adalah sangat kuat (Mulyadi dkk, 2020).

Praktik politik tata ruang di Kabupaten Tuban dapat dilihat melalui teori produksi ruang (theProduction of Space Theory) dari Henri Lefebvre (1991) bahwa perlu diadakan peralihan fokus perhatian dari hal-hal yang ada di dalam ruang (misalnya, alat-alat produksi seperti pabrik dan mesin) menuju kepada produksi aktual pada ruang itu sendiri (Lefebvre 1991). Artinya, politik tata ruang perlu 
memperluas kajiannya dari produksi menuju reproduksi. Ruang bukan hanya sebagai hal yang mati, tetap, statis dan tidak dialektis akan tetapi bila ruang diperlakukan bersama-sama dengan waktu, maka ruang dapat saja menjadi hal yang bersifat hidup, subur, kaya dan dialektis (Foucault, 1977). Dalam berbagai cara, ruang dapat membantu untuk mereproduksi sistem kapitalis serta pembentukan struktur kelas di dalam sistem tata ruang baru yang bersifat ekonomis.

Lefebvre membagi teorinya menjadi tiga hal sebagaimana disebutnya sebagai "Tripartite" atau tiga pihak. Pertama, praktik ruang (practice of space) yang meliputi produksi dan reproduksi ruang. Kedua, representasi ruang, (representation of space) atau ruang yang direpresentasikan oleh kaum elit politik seperti perencana, pengembang dan arsitek perkotaan. Ruang dalam representasi ruang menjadi ruang yang dianggap benar untuk mencapai dan memelihara sebuah dominasi dengan melakukan penyusunan program-program perencanaan atau pembangunan di sebuah perkotaan baik apakah itu berkaitan dengan proyek pembaharuan perkotaan (urbanmodernism) maupun dengan "pembersihan perkotaan”. Ketiga, ruang representasional (representational space) meliputi pengalaman-pengalaman hidup manusia di dalam ruang-ruang representasi yang direproduksi oleh kelompok-kelompok dominan.

Praktik politik tata ruang di Indonesia bukan merupakan hal yang baru lagi. Hal ini terlihat dari beberapa peneliti yang menfokuskan penelitinya pada politik tata ruang. Elvie Dyah (2014) melihat bagaimana praktik tata ruang yang ada di Kabupaten Magetan. Implementasi kebijakan tata ruang di Kabupaten Magetan sering terjadi permasalahan yang menghambat implemetasi kebijakan tata ruang seperti konflik, terjadinya alih fungsi lahan, defisit air bersih dan lain-lain. Penelitian ini menujukan bahwa implementasi kebijakan tata ruang di Kabupaten Magetan tidak sesuai dengan perda yang telah ditetapkan sehingga menimbulkan beberapa masalah. Siti Aminah (2015) melihat bahwa praktik penataan ruang khusunya di kota besar telah menimbulkan kontestasi dan konflik dengan melibatkan aktor pemerintah, masyarakat dan swasta. Galang Geraldy (2017) melihat bahwa adanya penetrasi kapital menyebabkan penataan ruang hanya berfokus pada sektor ekonomi saja tanpa melihat bagaimana dampaknya. Selanjutnya, penelitian Simatupang (2015) yang lebih memberikan sorotan pada masalah bagaimana masyarakat sosial dan lingkungan mempunyai pemahaman tentang imaginary bahwa perkotaan telah diproduksi melalui kapitalisme. Penelitian di atas melihat bahwa penataan ruang yang selama ini terjadi di Indonesia tidak sesuai dengan peruntukannya namun tidak ada yang melihat bagaiamana proses industrialisasi menyebabkan praktik penataan ruang semakin kompleks. Penelitian ini berusaha untuk mengisi kekosongan tersebut dengan melihat bagaimana proses industrialisasi semakin membuat praktik tata ruang semakin meningkat.

\section{METODE}

Penelitian ini menggunakan pendekatan kualitatif untuk menjelaskan permasalahan proses industialisasi menyebabkan praktik produksi terhadap tata ruang semakin meningkat. Observasi langsung dilakukan terhadap ruang-ruang yang sudah beralih fungsi dan juga mempelajari Perda Kabupaten Tuban Nomor 09 Tahun 2012 tentang Rencana Tata Ruang Wilayah Kabupaten Tuban Tahun 2012-2032. Penelitian ini juga melakukan wawancara dengan aktor yang mewakili pemerintah 
yaitu wakil bupati, Sekda Kabupaten Tuban dan Ketua DPRD Kabupaten Tuban untuk memperoleh gambaran praktik poltik tata ruang di Kabupaten Tuban. Data yang diperoleh dalam penelitian ini antara lain data jumlah penduduk, luas lahan pertanian, jumlah lahan yang dipersiapkan untuk industriserta peta lahan industrinya. Analisis data kualitatif yang dilakukan dalam penelitian ini dilakukan menggunakan proses verifikasi dari sumber data (informan). Data wawancara yang didapatkan dari para informan selanjutnya diinterpretasikan sesuai dengan kebutuhan penelitian dengan menggunakan metoe interpretatif.

\section{HASIL DAN PEMBAHASAN}

\section{Praktik Politik Penataan Ruang di Kabupaten Tuban}

Lefebvre (1991) melihat bagaimana politik tata ruang itu terjadi. Terdapat tiga pihak dimana praktik politik tata ruang itu terjadi. Pertama, praktik ruang (praktik ruang (practice of space) di mana ini terlihat dari pembangunan tata ruang yang berhubungan antara masyarakat, pemerintah dan swasta tidak bisa dikesampingkan. Mereka harus saling berhubungan untuk menciptakan tata ruang yang berkeadilan sehingga tidak menguntungkan salah satu pihak saja. Karena jika terjadi hal seperti ini maka akan menimbulkan konflik di tengah-tengah masyarakat sehingga akan menggangu proses penataan ruang tersebut. Sehingga hubungan antara masyarakat, pemerintah dan swasta perlu dijaga dengan baik.

Sebagai daerah yang industrinya tumbuh cukup pesat, Kabupaten Tuban yang menjadi daerah perlintasan di Pulau Jawa, menghubungkan Jakarta dan Surabaya, menempatkan kawasan industrinya di wilayah barat, yang mendekati perbatasan dengan Kabupaten Rembang, Provinsi Jawa Tengah. Kawasan pabrik-pabrik itu dikonsentrasikan di Kecamatan Jenu dan Tambakboyo.

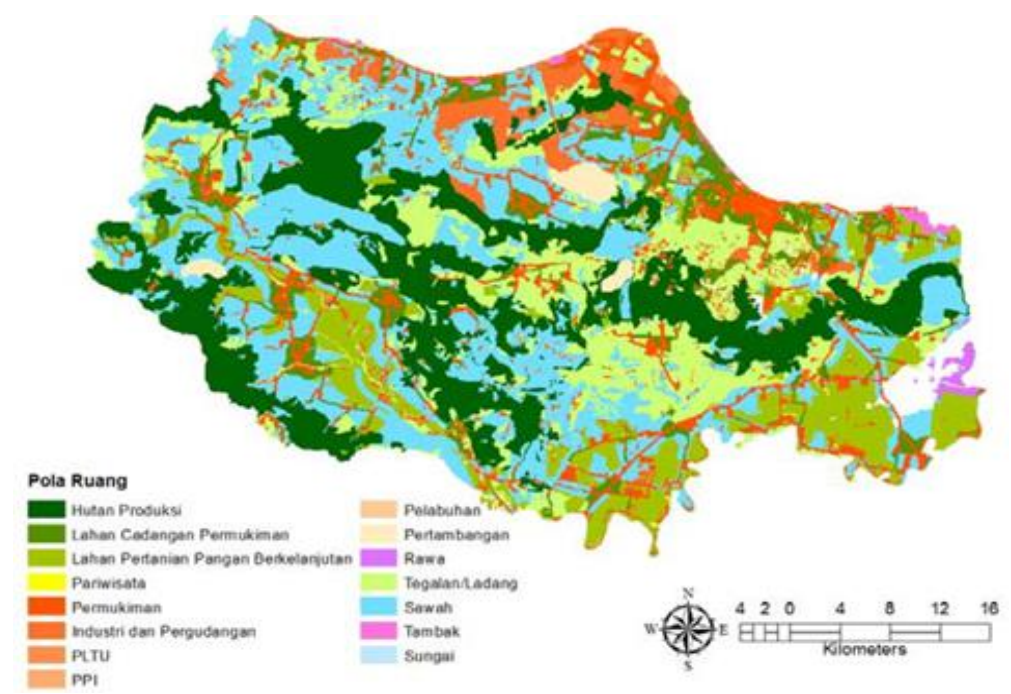

Gambar 1. Peta Alokasi Lahan sesuai dengan RTRW

Sumber : Badan Perencanaan Pembangunan daerah Kabupaten Tuban

Industrialisasi secara lebih masif, diawali oleh pendirian pabrik Semen Gresik di Tuban, yang merupakan anak perusahaan dari Semen Indonesia (SI). Pabrik semen membangun dermaga khusus di wilayah Jenu, untuk memperlancar gerak pemasaran dan distribusi. Selain itu industri besar lainnya di 
Tuban adalah minyak dan gas bumi, yang sudah memberikan sumbangan pajak sekitar Rp 17 Miliar. Industri Migas tersebut adalah, Pertamina EP Sukowati yang mengoperasikan Lapangan Mudi Control Procsesing Area (CPA) di Kecamatan Soko. Selain Semen Indonesia, di Kabupaten Tuban juga berdiri pabrik semen Holcim.

Industri Migas lainnya seperti, Pertamina Hulu Energi (PHE) yang mengoperasikan Pad C Mudi di Kecamatan Rengel dan Lapangan Gas Sumber di Kecamatan Merakurak. Pertamina EP Asset Cepu Field yang mengoperasikan Lapangan Tapen di Kecamatan Senori, Badan Usaha Milik Daerah (BUMD) Perusahaan Daerah Aneka Tambang (PDAT) dan PT Tawun Gegunung Energi (TGE) yang mengoperasikan Lapangan Migas di Kecamatan Singgahan. Selama ini Pertamina EP Sukowati Field dan Exxon Mobil Cepu Limited (EMCL), yang memiliki pipa distribusi minyak, yang melintas di Kecamatan Soko, Rengel dan Plumpang. Serta Kilang Minyak PT Trans Pacific Petrochemical Indotama (TPPI) dan Terminal BBM di Kecamatan Jenu.

Dalam sektor industri-industri besar ini, Pemerintah Kabupaten Tuban mempunyai Peraturan Daerah (Perda) yang mewajibkan pabrik-pabrik agar menyerap dan mengutamakan tenaga kerja asli warga Tuban. Sehingga secara sgnifikan akan mengurangi pengangguran usia produktif di Tuban. Selain itu Corporate Social Responsibility (CSR) perusahaan digunakan untuk membina industri kecil, mikro dan menengah (UMKM) dan beasiswa untuk pelajar di Tuban.

Pemeritah Kabupaten Tuban untuk rencana tata ruang pendidikan berupaya melakukan pemerataan di seluruh kecamatan. Untuk tingkat SMP dan SMA Negeri, semua kecamatan sudah ada. Sedangkan untuk SMK (Sekolah Menengah Kejuruan), sementara masih ada di wilayah eks pembantu bupati, belum bisa di setiap kecamatan. Namun SMK memang akan ditingkatkan, untuk mengimbangi pertumbuhan industri yang semakin pesat. Sehingga lulusan SMK yang siap kerja, bisa terserap untuk memenuhi kebutuhan tenaga di kalangan industri.

Sementara untuk kawasan perdagangan, tetap akan di pusat kota. Sebab, dengan banyaknya industri tentunya akan menaikkan potensi ekonomi, selain banyaknya pendatang sebagai pekerja, pendapatan perkapitan penduduk Tuban juga diperkirakan naik. Hal itulah yang diprediksi akan meningkatan pertumbungan sektor perdagangan. Sebab, pangsa pasarnya bertambah secara signifikan. Hal ini sesuai dengan teori transformasi kota bahwa pertambahan penduduk yang hadir di pusat kota akan mengisi ruang-ruang industri yang menyebabkan pada perluasan kota (Aldo Rosi, 1984).

Tuban dinilai punya potensi besar perekonomian terutama di sektor industri pengolahan, perdagangan dan pertambangan. Perdagangan menyumbang output Rp3 Triliun, industri pengolahan Rp 2,9 Triliun, Pertambangan Rp. 1,8 Triliun. Usaha rakyat yang cukup berkembang adalah budidaya padi, sapi potong, kacang tanah, penangkapan ikan laut dan penggalian batu kapur. Untuk populasi ternak sapi, Tuban nomer dua di Jawa Timur, setelah Sumenep.

Pemerintah Kabupaten Tuban berusaha untuk memberikan keseimbangan antara timur, barat, utara dan selatan. Misalnya Tuban Sport Center yang dibangun di wilayah Rengel. Begitu juga dengan rencana jalan Bypass, untuk mengurai kemacetan di wilayah kota, yang akan dibangun di wilayah 
selatan. Sementara itu, strategi untuk mengembangkan kawasan strategis, dalam mendorong pengembangan wilayah meliputi mengembangkan kawasan agropolitan yang terkonsentrasi di kecamatan Semanding, Palang, Plumbang, Widang dan Kecamatan Jatirogo.

Kawasan yang berpotensi menghasilkan produk unggulan pertanian yang akan dilengkapi dengan prasarana produksi dan juga pasar komoditas. Selanjutnya akan juga dilengkapi dengan sentra industri kecil, yang terdiri dari satu atau lebih pusat kegiatan industri pertanian dan pengelolaan sumber daya alam tertentu, yang diatur dengan tata ruang pemukiman dan sentra agrobisnis. Hal ini sebagaimana dikemukakan oleh Ansari et al. (2014) bahwa mengusahakan lahan dengan sistem mengintegrasikan berbagai macam komponen tanaman dengan agrobisnis lainnya salah satunya adalah peternakan.

Kabupaten Tuban banyak berdiri pabrik-pabrik dengan skala berat sehingga hal ini akan sangat berpengaruh dalam kehidupan masyarakat. Dalam hal pembangunan infrastruktur khususnya pembangunan jalan mereka melakukan iuran dalam membangun jalan tersebut. Khususnya jalan yang dilalui oleh kendaraan besar dari pabrik. Hal ini dilakukan karena rata-rata pabrik di Kabupaten Tuban menggunakan kendaraan dengan skala besar untuk mengangkut hasil produksi mereka. Dengan menggunakan kendaraan skala besar tersebut mengakibatkan jalan di Kabupaten Tuban cepat rusak sehingga harus segera di perbaiki. Untuk memperbaiki jalan yang rusak ini membutuhkan dana yang cukup besar sehingga dalam membangun atau memperbaiki sebagian menggunakan dana dari pabrik tersebut.

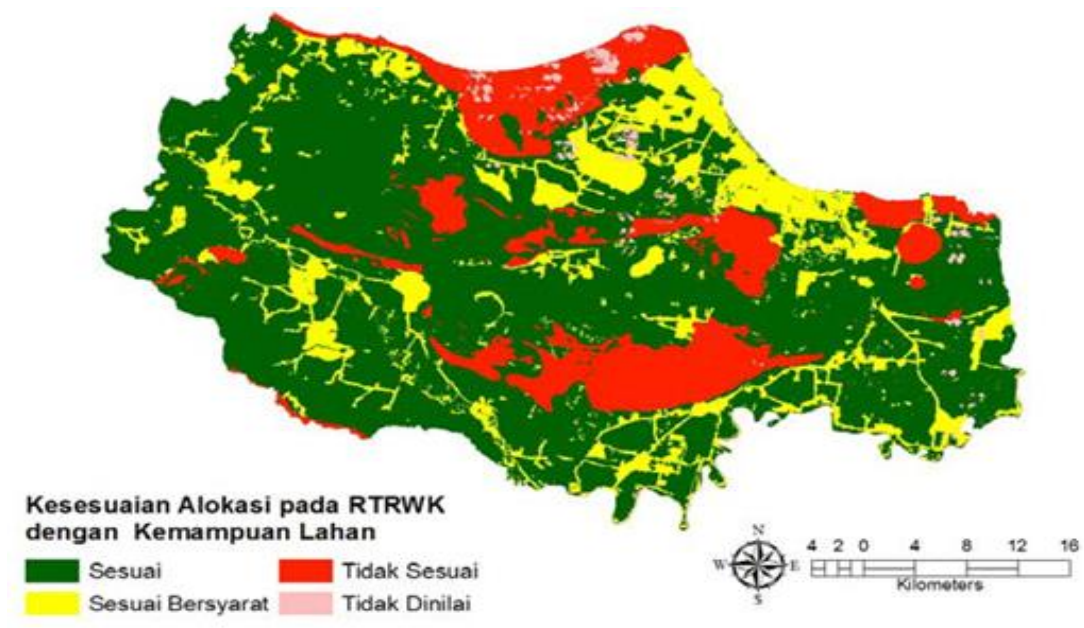

Gambar 2. Peta kesesuaian alokasi pada RTRW dengan kemampuan lahan

Sumber : Badan Perencanaan Pembangunan daerah Kabupaten Tuban

Berdasarkan peta di atas, dalam mendorong pertumbuhan ekonomi di Kabupaten Tuban, pemerintah daerah menyediakan tempat untuk didirikan pabrik yang lokasinya tidak banyak penduduknya sehingga aktifitas produksi tidak terganggu. Dalam hal ini pemerintah Kabupaten Tuban menyediakan tempat di Kecamatan Jenu, Tambak Boyo dan sebagian di Kecamatan Merakurak untuk di bangun lokasi pabrik. Pemerintah menyediakan tempat tersebut karena di daerah tersebut tidak lahanya tidak cocok digunakan untuk lahan pertanian sehingga dapat dimanfaatkan untuk dibangun 
pabrik. Selain itu juga daerah tersebut juga dilalui oleh jalur pantura sehingga memudahkan mobilitas produksi bagi pabrik-pabrik tersebut.

\section{Praktik Representasi Ruang (Representation of Space) di Kabupaten Tuban}

Representasi ruang adalah ruang yang dihasilkan atau direncanakan oleh elite politik seperti perencana, pengembang dan arsitek perkotaan (Simatupang; 2015). Jika dilihat pembangunan pabrik di Kabupaten Tuban hanya berfokus di bagian utara sehingga kegiatan ekonomi hanya terpusat di bagian utara sehingga menyebabkan disparitas antara kawasan utara dan kawasan selatan. Untuk mengurangi disparitas pembangunan antara utara dan selatan pemerintah daerah membangun Ring Roadsepanjang kurang lebih $20 \mathrm{KM}$ yang dialihkan ke selatan supaya menumbuhkan kegiatan ekonomi baru di kawasan selatan Tuban. Selain itu juga jalan Ring Road ini juga bertujuan untuk mengurangi kepadatan lalu lintas di kawasan utara Kabupaten Tuban. Karena selama ini lalu lintas sering terpusat di kawasan utara dan sering menimbulkan kemacetan. Selain itu juga dengan adanya kendaraan dari yang beskala besar hingga sepeda motor melewati satu jalur, hal ini mengakibatkan seringnya terjadi kecelakaan. Oleh karena itu, pemerintah membangun jalan Ring Road untuk mengatasi segala permasalahan yang ada di Kabupaten Tuban. Nantinya jalan Ring Road ini penggunaannya akan diawasi secara ketat. Jalan Ring Road ini dirancang dengan baik di mana nantinya tidak boleh ada banyak perempatan atau putaran balik. Selain itu juga pembangunan di sekitar Ring Road ini akan diawasi dengan ketat sehingga ketika sudah jadi maka kendaraan besar dapat melaju dengan cepat sehingga dapat mengurangi kemacetan. Pembangunan jalan Ring Road ini semua dananya berasal dari APBD Kabupaten Tuban. Pembebasan lahan untuk jalan Ring Road tersebut sudah selesai dan di tahun 2019 pembangunan fisik jalan Ring Road tersebut sudah dimulai.

Politik tata ruang di Kabupaten Tuban, Jawa Timur, tidak bisa dilepaskan dari kebijakan dasar yang tertuang dalam Peraturan Daerah (Perda) Nomor 9/2012 tentang Tata Ruang dan Wilayah (RTRW) Tuban. Kebijakan dasar tentang posisi, penggunaan, peruntukkan, dan alih fungsi (konversi) lahan berlaku selama 20 tahun. Perda ini secara normatif baru bisa ditinjau kembali pada tahun 2032 mendatang. Seiring dengan banyak perkembangan, khususnya akibat pertumbuhan ekonomi dan demografi, dimungkinkan sekali untuk dilakukan proses peninjauan kembali atas Perda tersebut setidaknya dalam tempo 5 tahun. Syaratnya terjadi deviasi atas rencana Perda tersebut yang volumenya sekitar 30 persen. Hal ini sebagaimana disampaikan oleh Wakil Bupati Tuban, Noor Nahar Husain, bahwa peninjauan kembali isi Perda tentang RTRW bisa dilakukan sekali dalam 5 tahun, di mana dalam proses implementasinya melibatkan banyak organisasi pemerintah daerah (OPD), seperti Sekretaris Daerah (Sekda), Bappeda, Dinas Pekerjaan Umum Cipta Karya, Dinas Pekerjaan Umum Bina Marga, dan OPD lainnya. Perubahan dan peninjauan kembali itu tidak dapat dilakukan secara tergesa-gesa tanpa sistem perencanaan yang matang dan komprehensif.

Dalam perspektif sekarang dan ke depan, konversi lahan di Kabupaten Tuban merupakan realitas yang tidak mungkin dihindarkan. Konversi lahan itu ditentukan banyak faktor dan satu di antaranya adalah karakter geologi lahan itu sendiri. Kabupaten Tuban selain dikenal sebagai daerah 
pertanian, terutama untuk kawasan di daerah aliran Sungai Bengawan Solo, juga memiliki luasan tambang batu kapur, dolomit, dan pasir kuarsa yang tak kecil. Misalnya, konversi lahan untuk kepentingan industri pertambangan direncanakan seluas 2.000 hektar diperkirakan akan berkembang dan bertambah menjadi minimal 2.400 hektar. Sedang untuk sektor industri yang sekarang diizinkan mencapai 12.000 hektar.

Kegiatan pertambangan, khususnya batu kapur, pasir kuarsa, dan dolomit itu terutama berada di Kecamatan Merakurak, Kerek, Montong, Rengel, dan Sooko. Tak hanya kegiatan pertambangan yang diperkirakan mengalami akselerasi pertumbuhan dinamis di Tuban dalam beberapa tahun ke depan, kebutuhan lahan untuk jalan raya di daerah ini juga menjadi sektor kebutuhan strategis yang mesti dipersiapkan sebaik mungkin. Pemerintah Kabupaten Tuban mengalokasikan dan merencanakan lebar jalan provinsi di Tuban mencapai 150 meter, jalan kaboaten selebar 100 meter, dan jalan desa selebar 50 meter. Dalam tempo dekat, Pemkab Tuban akan membangun jalan ring road (jalan lingkar) sepanjang 19,8kilometer (KM) dari Kecamatan Semanding sampai Kecamatan Jenu. Tujuannya, agar semua kendaraan besar, seperti truk, bus, dan lainnya tak masuk jalan-jalan di kawasan kota. Sehingga resiko terjadinya kecelakaan di jalan-jalan kawasan perkotaan bisa diminimalisir sekecil mungkin. Ring road Kabupaten Tuban lahannya telah dibebaskan Pemkab Tuban beberapa tahun lalu dengan nilai sebesar Rp 170 miliar. Ring road ini biasa kontruksinya diperkirakan menghabiskan anggaran Rp 600 miliar, dengan lebar badan jalan 35 meter (4 lajur). Saat perencanaan awal, anggaran konstruksi yang dibutuhkan untuk pembangunan ring road hanya Rp 400 miliar dan ditanggung Pemerintah Pusat di Jakarta (Kementerian PUPR). Tapi, hingga menjelang akhir tahun anggaran 2018, tak kunjung ada kucuran anggaran dari Pemerintah Pusat, sehingga Pemkab Tuban pada tahun anggaran 2019 mendatang mengalokasikan anggaran sebesar Rp 70 miliar untuk pembangunan konstruksi jalan lingkar tersebut. Akibat terbatasnya anggaran, volume proyek jalan lingkar ini juga menyusut, di mana lajur badan jalan yang semula direncanakan sebanyak 4 lajur menjadi cukup hanya 2 lajur.

Merujuk pada Perda Nomor 9/2012 tentang RTRW Kabupaten Tuban, disediakan luasan lahan mencapai 12.000 hektar untuk kepentingan sektor industri. Lahan tersebut tersebar di sejumlah kecamatan di Kabupaten Tuban, di antaranya di Kecamatan Tuban Kota, Jenu, Merakurak, Kerek, dan Tambakboyo. Lahan ini juga nantinya diperuntukkan pada rencana kegiatan industry refinery (pengolahan) minyak dan gas (Migas) bumi di Kabupaten Tuban yang melibatkan PT Pertamina dan Rosnevt, perusahaan migas dari Rusia. Untuk kepentingan ini diperlukan lahan seluas 1.000 hektar yang membentang di sepanjang garis pantai antara Kecamatan Jenu sampai Kecamatan Tambakboyo, Kabupaten Tuban. Pembangunan proyek strategis di sektor migas ini diperkirakan menelan investasi sekitar Rp 200 triliun. Sampai sekarang, informasi aktual yang ada menyebutkan, sebanyak 111 kepala keluarga (KK) yang menempati lahan seluas 293 hektar yang belum sepakat lahannya dibebaskan untuk kepentingan proyek strategis ini. Sebab, warga mengajukan tuntutan mereka bisa dipekerjakan di proyek ini termasuk setelah proyek ini operasional, sehingga mereka tak menjadi penonton di tanah atau daerahnya sendiri. Tuntutan itu, secara faktual, dibenarkan Gubernur Jatim saat itu, Dr H Soekarwo dan 
Wabup Tuban Noor Nahar Husain. Sekiranya proyek refinery migas di Tuban gagal diwujudkan karena peliknya proses pembebasan lahan, tak menutup kemungkinan nilai investasi sangat besar sector migas ini dialihkan ke Kabupaten Situbondo. Awalnya rencana proyek kilang minyak di Tuban ini hanya membutuhkan lahan sekitar 348 hektar sampai 400 hektar. Tapi, kemudian berkembang sampai 1.000 hektar yang membentang di sepanjang garis pantai Kecamatan Jenu sampai Kecamatan Tambakboyo, Tuban. Lahan yang direncanakan dipergunakan untuk kilang minyak itu tak hanya milik warga dan lahan yang telah dimiliki PT Pertamina, namun ada pula lahan yang di bawah kekuasaan dan pengelolaan PT Perhutani. Baik Gubernur Soekarwo maupun Wabup Noor Nahar Husain mengakui, pembebasan lahan milik PT Perhutani untuk proyek kilang minyak di Tuban juga bukan hal mudah dilakukan. Soekarwo memandang perlunya diskresi kebijakan terkait lahan tanah untuk proyek industri strategis dalam konteks ini.

Salah satu potensi besar Kabupaten Tuban adalah besarnya volume deposit batu kapur, dolomit, dan sumber daya mineral lainnya di daerah ini. Kini ada 2 pabrikan semen besar beroperasi di Tuban: PT Semen Indonesia (Semen Gresik) dan PT Holcim Indonesia. Dalam perkembangannya, Semen Holcim Indonesia dibeli PT Semen Indonesia dengan nilai sekitar Rp 13,5 triliun. Kedua pabrikan semen besar di Indonesia memproduksi semen dari pabrik yang beroperasi di Tuban sekitar 17,5 juta ton per tahun atau setara dengan 25 persen pasokan permintaan semen nasional pada 2017. Luasan lahan batu kapur, dolomit, dan sumber daya mineral lainnya di Tuban diperkirakan mencapai 40 hektar. Kekayaan alam itu tersebar di sejumlah kecamatan di Tuban, seperti di Kecamatan Palang, Semanding, Merakurak, Kerek, dan Montong.

PT Semen Indonesia melalui anak perusahaannya, PT Semen Gresik, telah mengantongi konsesi lahan penguasahaan dan eksploitasi batu kapur di Tuban seluas 1.100 hektar dan semen Holcim Indonesia seluas 300 hektar. Sedangkan potensi lahan batu kapur di Tuban diperkirakan mencapai 40.000 hektar. Wabup Tuban, Noor Nahar Husain mengutarakan, sekalipun masih terbuka peluang bagi kedua pabrikan semen besar itu memperluas lahan eksploitasinya, tapi pihaknya bersikap prudent jika ada permohonan penambahan luasan konsesi lahan batu kapur untuk kepentingan industri. Faktor keseimbangan lingkungan hidup adalah poin penting yang harus diperhatikan dan menjadi bahan pertimbangan utama ketika lisensi tentang pemanfaatan lahan batu kapur diajukan investor. Prinsipnya, izin usaha tak mungkin bisa keluar dari kebijakan dasar tata ruang yang diatur dalam kebijakan tata ruang dalam Perda RTRW Tuban. Artinya, investor sektor industri akan diarahkan pada zona-zona yang telah ditentukan untuk industri. Selain itu, pengambil dan pelaku kebijakan di Tuban tak bisa memanfaatkan akses informasi yang digenggamnya untuk kepentingan pribadi sebagai broker atau makelar. Pemerintah Kabupaten Tuban menyadari bahwa tanpa industrialisasi tak mungkin mampu menderek akselerasi pembangunan ekonomi dan sosial di Tuban secara cepat (McGee, 2009; Unwanullah, 2015; Geraldy, 2017).

Industri skala besar yang masuk dan beroperasi di Tuban memang belum banyak jumlahnya. Selain PT Semen Gresik, Holcim Indonesia, dan PT TPPI, nyaris belum ada industri skala besar lainnya 
yang beroperasi di Tuban. Industri skala menengah dan kecil mulai tumbuh di Tuban dalam beberapa tahun terakhir. Dalam tempo 5 tahun terakhir, menurut Wabup Noor Nahar Husain, terjadi konversi lahan pertanian ke nonpertanian, khususnya perumahan, sekitar 30 hektar. Untuk konversi lahan pertanian ke nonpertanian di luar perumahaan juga sekitar 30 hektar. Luasan konversi lahan pertanian ke nonpertanian yang relatif kecil tersebut diperkirakan bakal mengalami perubahan signifikan pada beberapa tahun ke depan ketika kilang minyak PT Pertamina dan Rosnevt Rusia benar-benar ditempatkan dan beroperasi di Tuban.

Secara keseluruhan, volume luasan lahan yang diperuntukkan untuk kegiatan industri di Tuban mencapai sekitar 10.000 hektar. Sekretaris Daerah Kabupaten Tuban, Dr Budi Wiyana mengatakan, lahan untuk industri dipusatkan di sejumlah kecamatan di Tuban, seperti Kecamatan Jenu, Tambakboyo, Bancar, Kerek, Merakurak, Rengel, dan Sooko. Budi Wiyana menambahkan, geliat konversi lahan pertanian ke nonpertanian, terutama industri, di Tuban mulai terjadi pada 2012 sampai sekarang. Industri yang masuk adalah luberan dari Kota Surabaya dan Kabupaten Gresik yang tak mungkin tertampung di kedua daerah tersebut. Nilai tambah lain bagi Tuban menarik kalangan industri adalah besaran upah minimum kabupaten (UMK) yang jauh lebih rendah dibandingkan Kota Surabaya dan Kabupaten Gresik. Karena itu, kebutuhan merevisi Perda Nomor 9/2012 tentang RTRW Tuban mulai digarap dan tahapannya sekarang melakukan sinkronisasi data dengan Badan Pertanahan Nasional (BPN) Tuban

\section{Paktik ruang representasional (representational space) di Kabupaten Tuban}

Ruang representasional meliputi pengalaman-pengalaman hidup manusia di dalam ruang-ruang representasi yang direproduksi oleh kelompok-kelompok dominan. Hal ini terlihat dari pemerintah melakukan upaya pengendalian alih fungsi lahan pertanian pangan melalui Undang-Undang Nomor 41/2009 tentang Perlindungan Lahan Pertanian Pangan Berkelanjutan. Pemerintah menetapkan dalam UU tersebut bahwa Lahan Pertanian Pangan Berkelanjutan (LP2B) adalah bidang lahan pertanian yang ditetapkan untuk dilindungi dan dikembangkan secara konsisten guna menghasilkan pangan pokok bagi kemandirian, ketahanan dan kedaulatan pangan nasional. LP2B dapat berupa lahan beririgasi, lahan reklamasi rawa pasang surut dan nonpasang surut dan/atau lahan tidak beririgasi/lahan kering. Penetapan kebijakan LP2B merujuk pada pertumbuhan penduduk dan kebutuhan konsumsi pangan penduduk, pertumbuhan produktivitas, kebutuhan pangan nasional, kebutuhan dan ketersediaan lahan pertanian pangan, pengembangan ilmu pengetahuan dan teknologi serta musyawarah petani. Kebijakan operasional dan implementatif masalah ini diatur lebih detail dalam ketentuan tentang Penetapan dan Alih Fungsi Lahan Pertanian Pangan Berkelanjutan yang diatur PP Nomor 1/2011. Jika suatu daerah/kawasan ditetapkan sebagai Lahan Pertanian Pangan Berkelanjutan, maka pemerintah daerah bertanggung jawab terhadap pelaksanaan konservasi tanah dan air yang meliputi, perlindungan sumber daya lahan dan air, pelestarian sumber daya lahan dan air, pengelolaan kualitas lahan dan air serta pengendalian terhadap pencemaran.dalam penetapan LP2B, hak yang dimiliki masyarakat harus diperhatikan dengan diberikan insentif berupa keringanan Pajak Bumi dan Bangunan(PBB), pengembangan infrastruktur pertanian, pembiayaan penelitian dan pengembangan benih dan varietas 
unggul, kemudahan dalam mengakses informasi dan teknologi, penyediaan sarana dan prasarana produksi pertanian, jaminan penerbitan sertifikat bidang tanah pertanian tanaman pangan, serta penghargaan bagi petani berprestasi tinggi.

Penelitian yang dilakukan Pemerintah Kabupaten Tuban dengan melibatkan peneliti dari Institut Pertanian Bogor (IPB) diperoleh data bahwa luasan lahan pertanian produktif di Tuban sekitar 50 ribu hektar. Dari luasan tersebut, minimal dibutuhkan luasan lahan pertanian 30 ribu hektar untuk kepentingan target dan tujuan ketahanan pangan Tuban hingga 30 tahun ke depan. Penelitian tentang LP2B di Tuban dengan melibatkan IPB tersebut juga menghasilkan kesimpulan bahwa sekitar 50 persen produksi pertanian di Tuban dikirimkan untuk memenuhi kebutuhan pangan daerah lainnya di Jawa Timur maupun provinsi lainnya di Indonesia (Iswi \& Budi Santoso, 2015)

Kawasan pertanian di Tuban umumnya tersebar di kecamatan-kecamatan yang berada di Daerah Aliran Sungai (DAS) Sungai Bengawan Solo, antara lain di Kecamatan Sooko, Rengel, Semanding, Pakah, Widang, dan lainnya. Budi Wiyana mengatakan, lahan pertanian produktif tersebut harus diproteksi dengan kebijakan pemerintah yang tertuang dalam peraturan daerah (Perda). Pemkab Tuban memiliki agenda planning untuk memasukkan lahan pertanian produktif masuk kategori LP2B tersebut dalam revisi Perda Nomor 9/2012 tentang RTRW Tuban. Masalahnya merumuskan kebijakan LP2B atas lahan pertanian produktif di Tuban bukan hal mudah. Banyak faktor yang mesti dipertimbangkan dan dikalkulasikan secara teknis dan detail, terutama kesepakatan dengan pemilik lahan pertanian produktif untuk tidak mudah begitu saja dalam melego dan atau menjual lahan pertanian produktif miliknya kepada pihak lain untuk kepentingan sektor non-pertanian.

Secara faktual, ada 2 komoditas pertanian di Tuban yang menjadi unggulan, yakni padi dan jagung yang tercatat unggul di Jawa Timur. Potensi Tuban di bidang pertanian sangat melimpah, utamanya komoditas pangan seperti padi dan jagung. Hal itu didukung karena topografi Tuban berada di Daerah Aliran Sungai (DAS) Bengawan Solo, Karena itu, potensi tanaman padi sangat melimpah. Untuk perbatasan hutan juga dimanfaatkan untuk tanaman jagung dan kacang tanah. Luas Tambah Tanam (LTT) Tuban untuk tanaman padi dalam 7 tahun terakhir selalu melampaui target. Hal itu berdampak pada jumlah produksi beras yang mengalami surplus hingga 60,06 persen. Seperti di tahun 2017, dari target 101.913 hektar dapat terealisasi seluas 103.238 hektar. Di tahun 2017 produksi padi dari target 607.316 ton, hingga akhir 2017 dapat terealisasi hingga 627.774 ton. Untuk tanaman jagung, dari target LTT 2017 seluas 97.067 hektar hingga akhir 2017 dapat terealisasi 119.118 hektare. Produksi jagung mengalami peningkatan signifikan yakni sebesar 610.854ton dari target produksi sebesar 528.853 ton. Angka ini telah mengukuhkan Tuban jadi penghasil jagung terbanyak di Jawa Timur. Pada tahun 2018 ini, target Luas Tambah Tanam(LTT) tanaman padi seluas 105.721 hektar, dengan target produksi sebanyak 629.859 ton (Suwarto \& Prihantoro, 2020).

Peningkatan produktivitas sektor pertanian, industri, dan sektor perekonomian lainnya diharapkan mampu menderek angka Produk Domestik Regional Bruto (PDRB) Tuban dari tahun ke tahun. Pada 2017 lalu, tingkat PDRB Tuban mencapai Rp 52 triliun. Angka itu baru sekitar 4-5 persen 
dibandingkan angka PDRB Jatim yang diperkirakan mencapai sekitar Rp 2.000 triliun lebih sedikit. Pada 2019 mendatang, tingkat APBD Tuban mencapai Rp 2,4 triliun, dengan tingkat PAD sebesar Rp 412 miliar. Itu artinya, Tuban masih membutuhkan banyak kucuran anggaran dari tingkat pemerintah lebih tinggi, baik Pemprov Jatim maupun Pemerintah Pusat di Jakarta. Peningkatan PDRB, APBD, dan PAD selain tingkat inflasi, Indeks Pembangunan Manusia (IPM) dan Indeks Gini Ratio adalah indikator penting pembangunan Tuban yang bersifat multiperspektif.

\section{SIMPULAN}

Penataan ruang di Kabupaten Tuban selalu melibatkan antara pemerintah, swasta dan masyarakat. Dalam hal ini pemerintah daerah Kabupaten Tuban berusaha agar penataan ruang tidak hanya dinikmati oleh segelintir orang saja. Pemerintah daerah berusaha supaya pertumbuhan ekonomi di Kabupaten Tuban dapat dinikmati oleh semua masyarakat. Dalam penataan ruang pemerintah berusaha kegiatan ekonomi tidak hanya terpusat di kawasan utara saja namun juga kawasan selatan agar perekonomiannya juga tumbuh. Pemerintah mendorong agar pabrik yang didirikan di kawasan tuban sebagian besar pegawai berasal dari masyarakat Kabupaten Tuban. Hal ini dilakukan supaya masyarakat dapat menikmati pertumbuhan ekonomi di Kabupaten Tuban. Pemerintah juga mendorong supaya pabrik tersebut tidak fokus dalam membangun infrastruktur namun juga membangun sumber daya manusia. Pemerintah mendorong pabrik supaya memberikan beasiswa kepada para siswa supaya dapat menempuh pendidikan yang layak sehingga nantinya mereka akan mendapatkan perkerjaan yang layak sehingga dapat membangun sumber daya manusia yang unggul.

Mengingat pembangunan pabrik yang semakin meningkat, pemerintah daerah juga membuat regulasi untuk melindungi kawasan pertanian mereka. Hal ini bertujuan supaya kawasan pertanian yang produktif tidak dibangun pabrik karena Kabupaten Tuban merupakan salah satu lumbung padi nasional yang menyubang ketahanan pangan nasional. Dengan adanya regulasi tersebut nantinya tidak ada lagi pabrik yang dibangun di lahan yang tidak semestinya dan untuk menghindari konflik di masyarakat. Selama ini pemerintah Kabupaten Tuban berusaha supaya penataan ruang di Kabupaten Tuban tertata dengan baik sehingga penataan ruang di Kabupaten Tuban dapat dinikmati semua kalangan.

\section{DAFTAR PUSTAKA}

Aminah S (2015) Konflik dan kontestasi penataan ruang Kota Surabaya. MASYARAKAT: Jurnal Sosiologi, 59-79.

Ansari MA, Prakash N, Baishya LK, Punitha P, Sharma PK, Yadav JS, Kabuei GP, Levis Ch Kl (2014) Integrated Farming System: An ideal approach for developing more economically and environmentally sustainable farming systems for the Eastern Himalayan Region. Indian Journal of Agricultural Science. 84(3): 356-362.

Bupati Tuban Provinsi Jawa Timur (2016) Peraturan Daerah Kabupaten Tuban Nomor 7 Tahun 2016 tentang Perubahan atas Peraturan Daerah Nomor 2 Tahun 2014 tentang Izin Pemanfaatan Ruang di Kabupaten Tuban. 
Fitriana ED (2014) Implementasi kebijakan tata ruang wilayah dalam mewujudkan pembangunan kota berkelanjutan (Studi di Kabupaten Magetan). Jurnal Administrasi Publik, 2(2), 217-223.

Geraldy G (2017) Determinasi kapitalisme industri dalam politik penataan ruang perkotaan di Kabupaten Gresik. Jurnal Pemikiran Sosiologi, 4(1), 25-41.

Iswi A \& Budi SE (2015) Perwilayahan Komoditas unggulan tanaman pangan berdasarkan kesesuaian lahan Kabupaten Tuban. Jurnal Teknik ITS, 4(1).

Lefebvre H (1991) The Production of Space. Oxford: Blackwell. Leggewie, Claus.

McGee TG (2009) The Spatially of Urbanization: The Policy Challenges of Mega-Urban and Desakota Regions of Southeast Asia, UNU-IAS Working Paper No. 16.

Mulyadi L, Witjaksono A, Fathony B (2020) Karakterk Kawasan dan Arsitektur Kota Malang Jawa Timur. Malang: Dream Litera Buana.

Rosi A (1984) The Architecture of the City. Cambridge: MIT Press.

Suwarto \& Prihantoro I (2020) Studi pengembangan jagung berkelanjutan melalui integrasi dengan sapi di Tuban, Jawa Timur. Jurnal Ilmu Pertanian Indonesia (JIPI), 25(2), 232-238.

Simatupang S (2015) Eco-Imaginary: Pendekatan untuk pengembangan kota yang berkelanjutan. Scale, 2(2).

Unwanullah A (2015) Industrialisasi dan tantangannya pada sektor pendidikan. Jurnal Economia, 11(2). 